\title{
イスラーム金融の発展とPPP 投資への影響
}

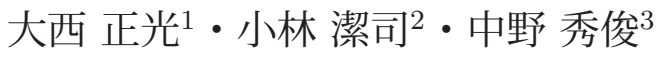 \\ 1正会員 京都大学大学院工学研究科都市社会工学専攻（ $=$ 615-8540 京都市西京区京都大学桂） \\ E-mail:masa@psa.mbox.media.kyoto-u.ac.jp \\ 2フェロー会員＼cjkstart京都大学経営管理大学院経営管理講座（广 606-8501 京都市左京区吉田本町） \\ E-mail:kkoba@psa.mbox.media.kyoto-u.ac.jp \\ 3 正会員 京都大学経営管理大学院（干 615-8540 京都市西京区京都大学桂） \\ E-mail: nakano.h@at2.ecs.kyoto-u.ac.jp
}

\begin{abstract}
民間資金を活用して，インフラストラクチャーの建設及び維持管理運営を行う PPP (Public-Private Partnership) は世界的な潮流となっている. PPP 事業における資金調達先も多様化する中，イスラーム金融が果た す役割が大きくなっている．本研究ではイスラーム金融の発展が PPP 投資に与える影響を分析するため，イス ラーム金融に拈ける金利決定メカニズムを明示的に表現したイスラーム金融市場モデルを定式化する．その結 果, イスラーム金融の利益配分率 (疑似利子率) は, 預金, 貸出の両市場に㧈いて, 通常金融の利子率よりも小 さくなることが示された，さらに，預金者のイスラームに対する自覚が高まるほど，疑似貸出利子率が低下す る一方，イスラーム金融に伴う取引費用が軽減されれば，疑似貸出利子率が増大することが示された.
\end{abstract}

Key Words : Islamic finance, public private partnerships, two-sided market, Shari'ah compliance

\section{1. はじめに}

民間資金を活用して,インフラストラクチャーの建設 及び維持管理運営を行うスキームである PPP (PublicPrivate Partnership) は世界的な潮流となっている. 特 に急速なインフラ需要に直面している開発途上国では, PPP は国家発展のための重要な政策に位置づけられて いる．PPP が世界的に普及するにつれて，開発資金の 調達先も多様化しつつある. インフラ開発が活発であ る新興国の中には, 中東やマレーシアのようにイスラー ム教を国教とする国も少なくない.

イスラーム教は, 単なる宗教的思想だけではなく, 生 活に密接に関連した事柄をも対象として，幅広く宗教 的規則を定めている。このような，規則を一般にイス ラーム法（Shari'ah：以下, シャリア）と呼ぶが，イス ラム教を国教とする国では, シャリアを遵守すること が望ましいとされる。特に, 金融取引に関しても, 一 般的な金融取引概念とは異なり, シャリアでは「利子」 の概念が禁止されている. イスラーム社会の金融では, 融資者は利子から利益を得るのではなく, 事業に出資 という形で資金を提供し，PLS (Profit/Loss Sharing; 損益分担方式) に基づいて利益を得る. イスラーム教国 においては, 通常の金融取引方法とは異なり, シャリア に則った金融取引を行うイスラーム金融が発達してい る.イスラーム教国においても，必ずイスラーム金融 によって金融取引をしなければならないと義務づけら れているわけではない. しかし，イスラームの自己意
識の高まりを受けて，イスラームの教えに則った方法 に準じた金融取引のニーズが高まっている．2008 年時 点で，イスラーム金融の資産規模は，世界全体の金融 資産規模の $1 \sim 2 \%$ 程度であるが, 2000 年以降イスラー 么金融は資産残高ベースで年 15～20\%の高い率で成長 を続けており，国際金融の中でも無視できない存在に なっている1).

プロジェクトファイナンスでは, 資金調達費用を抑 制することにより競争力を確保することが重要な課題 となる. プロジェクトファイナンス事業における資金調 達戦略において，イスラーム金融は無視できない資金 調達手段の一つとなりつつある。イスラーム金融の更 なる発展が，今後のPPPを通じた社会資本整備投資と 資金調達費用に，どのような影響を及ぼすのかを検討 するためには, イスラーム金融の市場構造を明示的に 説明するモデルが必要である，イスラーム金融は，資 本市場から金融資源を調達する際のコンベンショナル な金融（以下，伝統的金融と呼ぶ）取引の代替的な取 引手段と見なすことができる。 その際に，イスラーム 金融に打ける貸出市場及び預金市場は，伝統的金融市 場との競争関係において存在している. その際，イス ラーム金融市場の預金利回りや貸出のマークアップ率 が, 伝統的金融市場との間の裁定を通じて, どのよう に決まるかは必ずしも明確ではない.

イスラーム金融は，伝統的金融とは異なる金融取引 手段であり，伝統的金融に対して代替的な資金調達手 段として成長しつつある。 その意味において，伝統的 
金融とイスラーム金融は, 金融取引のプラットフォー ムの差別化現象として見なすことができる. 本研究で は，このような取引のプラットフォームに関する競争

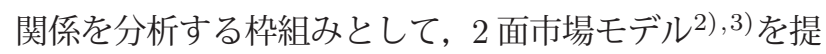
案する. イスラーム金融，伝統的金融ともに，金融市場 における取引手段という意味では，預金市場と貸出市 場の両方において，それぞれの取引手段を利用する人 が存在しなければならない. 本研究では, 以上のよう な 2 面市場モデルの枠組みを用いて，イスラーム金融 及び伝統的金融の競争関係をモデル化し，イスラーム 金融の存在理由とその市場メカニズムについて分析す る. さらに, 定式化したモデルに基づいて, 今後のイ スラーム金融の更なる発展が PPP 事業の資金調達費用 にもたらす影響について考察する. 以下, 2.では, 本 研究の基本的考え方を示すために, 既存の研究概要を レビューし, 本研究の新規性及び分析枠組みについて 説明する. 3. では, 2 面市場モデルとしてイスラーム 金融市場を考慮した金融市場モデルを定式化する４４． では, 3.のモデルに基づいて比較静学分析を行い, イ スラーム金融の発展が PPP 市場に及ぼす影響を分析す る. 5.では, 分析結果の政策的示唆を示す.

\section{2. 本研究の基本的考え方}

\section{(1) 既存の研究概要}

イスラーム金融の発展とともに, 学術研究レベルで もイスラーム金融への関心が高まっている．特に実務的 な要請から, イスラーム法学の分野では, 利子の解釈論 をはじめとして，イスラーム各国で用いられている取 引手法のシャリア適格性に関する多くの研究の蓄積が 存在する ${ }^{4)-6)}$. また, イスラーム金融というシステム がもたらす経済学的な意義について分析した文献も存 在する7)-9). イスラーム法では, 利子が禁止されてお り，PLSを採用することが原則である. Ebrahim and Safadi $^{10)}$ は, PLS が伝統的金融の負債契約よりも優位 であることを理論的に示している. また，イスラーム 金融が成長産業に長期金融の提供を促進する可能性に ついて指摘した研究がある11),12). しかし, 実際のイス ラーム金融の取引方式は, PLS 方式ではなく, 伝統的 金融の取引方式とほとんど差異がないことも報告され ている13),14). Chong and $\mathrm{Liu}^{13)}$ は, イスラーム金融が 急速に発展している理由が, PLSを採用していること による優位性によるものではなく，むしろイスラーム の自己意識の高まりによるものであると結論づけてい る. また, Aggarwal and Yousef ${ }^{14)}$ は, エージェンシー 問題が顕著になるほど, 負債型の契約方式が優位にな ることを理論的に示し，イスラーム金融において経済 合理的な理由で, PLS ではなく負債契約のような形態
が用いられると指摘している.

以上のようなイスラーム金融の経済学的研究は, 利 子の禁止, PLS といった取引形態が伝統的な金融と比 較しても経済的に合理的である点に着目してきた。一 方で，イスラーム金融に扔ける預金利回りや貸出利率 が，イスラーム銀行の意思決定を通じて，どのような メカニズムで決まるかについて分析した研究は, 筆者 の知る限り存在しない. 本研究では, イスラーム銀行 が直面する問題を, 預金市場, 貸出市場の 2 面市場に おける価格設定問題として定式化し, 預金利回り及び 貸出利率が決定されるメカニズムを明らかにする.

\section{（2）イスラーム金融}

資金の黒字主体から赤字主体に金融資源を仲介する という意味において，イスラーム金融も伝統的金融と 同様の機能を有する. しかし, イスラム金融と伝統的金 融は, その仲介のためのルールが異なる. 金融取引の 一取引方法としてのイスラーム金融を特徴づける重要 な要素の一つが,「利子 (riba)」という概念の禁止であ る. ただし，このことは単純に資金の融資者が利潤を得 ることを禁じているわけではなく, 共同出資等による 利潤の配分は古くから認められていた ${ }^{1)}$ 。このように, ある事業に共同して出資し, 出資割合に応じてその利 潤を獲得し，損失を負担する方式を PLS (Profit Loss Sharing; 損益分担方式）と呼ぶ. PLS の原則に則った スキームには, ムダラバ (mudarabah) やムシャラカ (musharakah) 等があるが, 今日のイスラーム金融に おいて, これらのスキームは全体の $5 \%$ 程度しか, 利用 されていない.

今日のイスラーム金融における実際の運用の実態を 見ると, ムラバハ (murabahah) やイジャラ（ijara）と いった実質的には, 通常の金融における利子と同じ機 能を有するスキームが用いられている，例えば，ムラ バハでは, 金融機関が売買契約の仲介を行うという形 でその価格差益から手数料及び利潤を回収する．この 価格差はあらかじめ確定しており, 利子ではなく手数 料という形で金融機関が貸出利率を設定したり, 売買 契約の価格差を利用した利潤の分配という形で預金利 回りが支払われる. すなわち, 形式的には, 利子の概念 を回避しているものの, 実質的な機能は, 通常の金融 取引における利子と同じである. 利用実態として, こ のように通常取引と経済学的に同等のスキームによる イスラーム金融が, 大半を占めていると見られている. また, 単純な金融商品だけではなく, デリバティブのよ うな先端的なイスラーム金融商品も生み出されている. 利子の解釈そのものについては，今日までに合意され た統一的な見解が存在しているわけでなく, その時代, 宗派や地域によっても異なっている。このような定義 
上の曖昧さにより，弾力的にシャリアを解橎すること で，通常の金融取引と本質的に同じものがイスラーム 金融商品として複製されていると考えられる，逆に言 えば，このように伝統的金融と同等の金融商品として 普及することにより，イスラーム金融が資本市場にお いて，急激に拡大してきたとも言える.

金融取引概念という意味で，イスラーム金融と伝統 的金融は，大半が同等であるが，融資対象となる事業に 関しては，イスラーム金融は伝統的金融と異なる，イ スラーム金融では，イスラム法において禁じられた物 品 (halam)（例えば, 豚肉, 酒類, たばこ, 武器など) に関連している事業は融資対象となり得ない，その意 味において, 通常の金融と比較して, 貸出先が制限さ れることになる．また，イスラーム金融で取引を行う ためには，取引のシャリア適格性を審査するためのシャ リア委員会の設置が必要となり,アレンジのために無 視できない費用を要する。 さらに，法的なインフラ整 備, 契約の標準化といった制度面の整備や，その運用を 司ることができる人材が不足している場合にも，相当 程度の取引費用を要することになる。このように，イ スラーム金融は，実態としては，通常の金融取引の方 法と機能的には同等であるが，イスラーム金融の場合， 取引対象の制限やアレンジ費用を要したり，制度面の 不備等が存在するため, 伝統的金融を利用した場合よ りも多くの取引費用が必要になると考えられる.

\section{（3）イスラーム金融の発展経緯}

イスラーム金融は，イスラームの自己意識を背景に， 自然発生的に出現した ${ }^{1)}$. 1950 年代後半には，パキス タンにおいて無利子銀行が設立された。結果としては, 資金の需給がつかず行き詰まったが，北村・吉田 ${ }^{1)}$ は, この動きが 1947 年にインドから独立したパキスタンに おいて，イスラームの独自性を顕現させようとしたイ スラーム回帰の動きであったとしている。また，1963 年のエジプトにおける貯蓄銀行というイスラームの教 義に則った農村金融機関の設立や，同 1963 年マレーシ アにおけるメッカ巡礼のための資金の貯蓄機関の発足 もイスラームの教義に則って運用されイスラーム銀行 設立の礎となった。このように，1970 年代の石油危機 とオイルマネーの出現以前の 1950 年代から 60 年代に かけて，イスラーム回帰の潮流の中で，イスラーム金 融の原始的な仕組みの試みが動き始めていた。

1975 年に, イスラーム諸国の社会経済発展を目的とし た「イスラーム開発銀行」(Islamic Development Bank; IDB）の設立は，イスラーム金融の発展にとって重要な 契機となった。オイルマネーの増大を背景にイスラー 厶金融の具体的な活動が開始された. その後，パキスタ ンやイランのように，国家の理念としてイスラームを
掲げる国の出現に伴い，国家レベルでイスラーム金融 の制度化に関する試みが行われた。同時に，中東やマ レーシアでは，民間主体によるイスラーム金融の取り 組みが開始され，1980 年代は，まさに試行錯誤とイス ラーム金融の手法が整理された時期であった. 1980 年 代までは，主にイスラーム教国の国内金融機関がイス ラーム金融を扱っていた. 1990 年代以降は，イスラー ム資金の増大を背景として，イスラーム金融機関に共 通する課題に取り組むための国際機関が設置され，イ スラーム金融の国際化が進展した．イスラーム金融の 国際化とともに，従来イスラーム金融を扱っていなかっ た大手の多国籍金融機関も，イスラーム金融市場に参 大し， 2000 年以降には急速にイスラーム金融を扱う機 関が増加している。

\section{（4）イスラーム金融市場の 2 面性}

イスラーム金融は, シャリアに則った取引を行うこ と自体に特別な価值を見出す人々によって利用される. 一方で，イスラーム金融から資金を借りる場合には，実 施しようとする事業がシャリアに則っていなければな らないという制約がある。イスラーム金融におけるイ スラーム銀行を介した間接金融では，イスラーム銀行 に預金することに特別な価值を見出す潜在的預金者の 需要と,イスラーム銀行の貸出市場における需要を同 時に考慮して，イスラーム銀行が預金利回り及び貸出 利率を設定する，本研究では，以上のようなイスラー ム金融における取引構造を 2 面市場モデル（two-sided model） ${ }^{2), 3)}$ に基づいて定式化し，イスラーム金融シス テムに拈いて，イスラーム銀行が預金利回り及び貸出 利率の決定するメカニズムを明らかにする.

クレジットカードのように，利用者の間で取引などの 相互活動を可能にするためのプラットフォーム（platform）を提供するような市場を 2 面市場と呼ぶ 2 . $。$ そ こでは,「取引を行う両サイドを同じプラットフォーム に乗せる」ことにより，ビジネスが成立するという特 徵がある．クレジットカードの例で言えば, Visa カー ドが多く用いられるためには, 商品の買い手と売り手 の両方が Visa カードのシステムに登録しておかなけれ ばならない.Visa カードを保有している人が仮に多く いたとしても，Visa カードを利用可能な商店の数が少 なければ, Visa カードを用いた取引の量は小さいまま に留まる．このように，2面市場では，商品の買い手側 の市場における需要の数と, 売り手 (商店) 側の需要 の数を適切にバランスさせる必要がある.

Rochet and Tirole ${ }^{3)}$ は， 2 面市場を以下のように定義 した．プラットフォームが用いられる取引量を $V$ ，プ ラットフォームの一方の利用者に対して課す取引あたり の料金を $a_{1}$, もう一方の利用者に対して課す取引あた 
りの料金を $a_{2}$ と表す.プラットフォームを通じた取引量 $V$ が, プラットフォームが課すすべての料金 $a=a_{1}+a_{2}$ にのみ依存するとき, プラットフォームの市場は, 「一 面的 (one-sided)」であると定義される. すなわち，プ ラットフォームの用いた取引量 $V$ は，2つの市場での 料金の分配には影響を受けない場合，市場が一面的で ある. 逆に, プラットフォームの総料金 $a$ を一定とし て, 一方の料金 $a_{1}$ を変化させることにより, 取引量 $V$ が変化するとき市場は 2 面的であると呼ぶ.

本研究では，イスラーム金融においても，このよう な 2 面市場の特性を有する点に着目する. イスラーム 銀行をイスラーム金融取引を仲介するプラットフォー ムであると解䣋することが可能である. イスラーム銀 行は, 預金者の預金需要と借り手の資金需要が乘離し ないよう配慮しなければならない. ある預金の利回り 水準で, 多くの預金を集めることができたとしても，イ スラーム銀行から資金を借り入れようとする借り手の 数が少なければ，実際に預金者と借り手の間で仲介さ れる資金の量は少ないままでとどまる。したがって,イ スラーム銀行は, 預金市場における利回りと貸出市場 における貸出利率を適切にバランスして設定すること により，実際に仲介する資金の量を増加させることが できる．イスラーム金融が有する市場の 2 面性という 性質は，一般的な金融市場では当てはまらない，伝統 的な金融市場では，預金市場，貸出市場の両方におい て, 競争的な環境に晒されている. 競争的環境によっ て決まる価格水準からの乘離は, 預金市場, 貸出市場 双方における顧客を多く流出させることになる。，一方 で，イスラーム金融では，預金市場，貸出市場の双方 に抢いて，一定の独占力を有している．このとき，イ スラーム銀行では, 預金利回り, 貸出金利の設定を通 じて，イスラーム金融の取引量を制御することができ るため, イスラーム金融市場の 2 面性を考慮すること は妥当である.

以上では，イスラーム金融の市場の 2 面性を説明す るために, クレジットカードの例を示した．この $2 つ$ が 2 面市場に直面しているという点では共通している が，イスラーム金融は, クレジットカードのケースと 比較して, 以下の点で異なる. クレジットカードの場 合，プラットフォームの利用そのものは非競合的であ る. したがって, 取引量は, 両サイドのメンバーの数に 対して比例的である。，一方，イスラーム金融の場合に は，このような非競合性は成立しない。貸出可能な資 金量は，預金量によって制約されざるを得ないという 意味において，プラットフォームの取引そのものが競 合的である. プラットフォームの競合性という点でク レジットカードとイスラーム金融のメカニズムは, 必 ずしも同一ではない. しかし, クレジットカードとイ
スラーム金融も，2つのサイドの利用者が同一のプラッ トフォームを活用して, 初めてその価值が生じるとい う 2 面市場の本質的な性質については共通しているこ とを指摘しておく.

\section{(5) 本研究の分析枠組み}

イスラーム金融を金融取引のプラットフォームの1つ であるという視点から分析することによって得られる 示唆について明らかにして扢う。 上述の通り，イス ラーム金融と伝統的金融ともに，預金者に利子を支払 い資金を集め，資金需要者へ有利子で貸し付けるとい う金融仲介の機能面においては，本質的な相違は見ら れないことを指摘した。 プラットフォームを取引を媒 介する方法として定義すれば, 伝統的金融もイスラー ム金融も金融取引のためのプラットフォームである.

イスラーム金融という伝統的金融と異なるプラット フォームが存在するということは, イスラーム金融で 取引することによって，伝統的金融では得られない付 加的な価值を提供することを意味する．このイスラー 么金融の付加的な価值は，伝統的金融という代替的な 取引手段が存在する市場環境の中でプライシングされ る. したがって, イスラーム金融をプラットフォームと して概念化し, イスラーム金融市場を 2 面市場として 定式化することによって, イスラーム金融という取引 手段の付加価值を明示的に考慮した PPP 投資のための 資本調達コストの内生的決定メカニズムを明らかにす ることができる. 本研究の主眼は, 今後のイスラーム 金融市場の発展が，イスラーム金融を活用した PPP 投 資の資本調達コストにどう影響を与えるかという問い に答えることにある。したがって, イスラーム金融と いう取引手段そのものの経済的価值を明示的に考慮し た金融市場モデルを定式化する必要がある．以下， 3. でイスラーム金融における利回りの決定メカニズムを 説明するイスラーム金融市場のプロトタイプモデルを 定式化する. その後，4.では，3.で定式化したモデル に基づいて, イスラーム金融市場の発展により変化す るパラメータ (人々のイスラームに対する自覚, イス ラーム金融取引の取引費用）に関して, 比較静学分析 を行い, PPP 事業のイスラーム金融を通じた資金調達 費用に与える影響を分析する.

\section{3. イスラーム金融市場モデル}

\section{（1） モデルの前提条件}

本研究では, 金融仲介機能を果たす銀行を, 図-1に 示すように，間接金融取引のためのプラットフォームと して位置づける，金融仲介は，預金者側からの資金供 給と, 借り手側の資金需要が両方, バランスしていな 


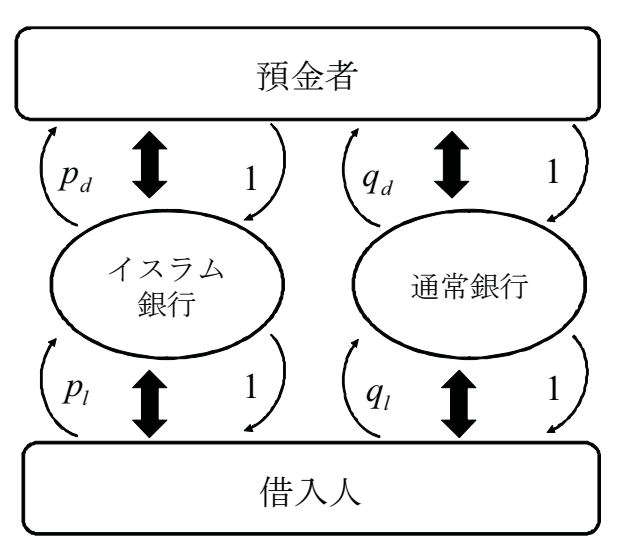

図-1モデルの構造

ければ成立しない．このような金融仲介の構造は，2面 市場モデルの枠組みを用いて定式化することができる.

イスラーム金融は，イスラーム教徒のイスラームに 対する自覚と回帰が原点となって発展してきた．この ことは，イスラーム教徒自身が，イスラームというア イデンティティそのものに対して, 何らかの価值を見 出していることを示している，金融という経済的な文 脈で解釈すると，イスラーム教徒の預金者は，自らの 預金がシャリア適格な事業のみを対象として投資され ることが保証されていることにより，通常の金融機関 に預金する場合と比べて，追加的な効用を得ると考え ることができる，イスラーム銀行は，通常の金融を扱 う銀行と異なり, 集めた預金者の預金を, シャリア適 格な事業のみを投資対象とすることを保証する間接金 融取引のプラットフォームとして機能している.

まず，基本モデルとして，完全競争的な伝統的金融市 場における銀行 (以下, 通常銀行と呼ぶ) と, イスラー ム金融を扱うことができるイスラーム銀行の 2 つのタ イプの銀行が存在している最も単純なケースを考える. シャリア適格な事業は, イスラーム金融市場の規模と比 して十分に存在していると仮定する. 前述したように, 通常銀行とイスラーム銀行の双方が，いずれも預金者 から一時的に預金を集め, 事後に追加的な金額を上乗 せ返済し, 貸し手からは, 貸し出した額面にマークアッ プを上乗せした額を事後に回収するという取引概念に おいて, 実質的に差異が存在しない, そこで, 図-1に 示すように通常銀行が預金者から 1 単位の預金を受け 入れた際に，約定する返済額（通常銀行の預金返済額） を $q_{d}$, イスラーム銀行が約定する返済額（イスラーム 銀行の預金返済額）を $p_{d}$ と表そう。伝統的金融の概念 では， $q_{d}-1$ が預金利子率に相当する．また，便宜的 にイスラーム金融の $p_{d}-1$ を疑似預金利子率と呼ぶ. また，通常の商業銀行が，資金の借り手が 1 単位の借 入を行った際に, 約定する返済額（伝統的金融の貸出
返済額）を $q_{l}$, イスラーム銀行が約定する返済額（イ スラーム金融の貸出返済額） $p_{l}$ と表す．伝統的金融の 概念では, $q_{l}-1$ が貸出利子率に相当する. また, 便 宜的にイスラーム金融の $p_{l}-1$ を疑似貸出利子率と呼 ぶ. 伝統的金融市場が，完全競争的であると仮定する と, 通常銀行が設定する利子率 $q_{l}, q_{d}$ は外生的に与え られ, $q_{d}=q_{l}=\bar{q}$ を満たす.

預金者の効用関数は，自身の預金がシャリア適格な 事業に投資されるかどうかに依存する. その程度は, 預 金者自身のイスラームに対する自覚の程度に依存して おり，個人間で異質性が存在している. すなわち，預金 者の効用は，1）預金先がイスラーム銀行かどうか，2） イスラームの自覚の程度の強さに依存する．このよう な預金者の効用を表現するために，以下のような，効 用関数を仮定する. 預金者がイスラーム銀行に預金し た場合に獲得する効用を $u_{S}$, 通常銀行に預金した場合 の効用を $u_{N}$ を表すと，

$$
\left\{\begin{array}{l}
u_{S}=p_{d}-1+\theta \\
u_{N}=q_{d}-1
\end{array}\right.
$$

と仮定する.ここで， $\theta$ は，預金者がイスラーム銀行に 預金した際に獲得する追加的な主観的効用（以下，イス ラーム効用と呼ぶ）である. 預金者のイスラーム効用 $\theta$ は, 非負の実数空間 $\boldsymbol{R}_{+}=[0,+\infty)$ 上において, 密 度関数 $f(\theta)$, 分布関数 $F(\theta)$ に従う確率変数であると 仮定する. ただし, $f(\cdot)$ の関数形は, $f^{\prime}(\cdot)<0$ を満た すと仮定する. なお，預金者は通常銀行かイスラーム 銀行のいずれかの銀行に必ず預金するため, 定数項の -1 は, 以降の分析で本質的な役割を果たさないが, 預 金前の効用を 0 として基準化していることを示す. 各 預金者は, 自らのイスラーム効用が確定した後に, 通 常銀行に預金するか, イスラーム銀行に預金するかを 決定する. ここで， $\theta \geq 0$ の仮定は，預金者が仮にイス ラーム金融への預金に対して, 特別な効用を得ないと したとしても，仮に金利が同等であれば，少なくとも イスラーム銀行と通常銀行が無差別になることを示し ている．言い換えれば，通常銀行とイスラーム銀行の 金利が同じである限り, 任意の預金者について, 強く 通常銀行が選択されることはない。

貸出市場には，潜在的に資本赤字主体（すなわち，借 り手) が存在している. 借り手は, 事業を実施する上 で，元手となる自己資金を保有せず，銀行からの借り 入れが必要である，基本モデルでは，借り手が有する 事業の収益率 $r$ は十分に大きく, 潜在的な借り手は, イ スラーム銀行か通常銀行のいずれかの銀行から借り入 れが可能であると仮定する。借り手がイスラーム金融 を採用するイスラーム銀行から融資を受ける場合には, 事業がシャリア適格でなければならない. シャリア適格 かどうか, 問題にならない事業も多いであろう。一方, 


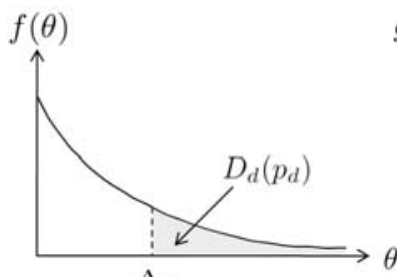

$\Delta_{d}$

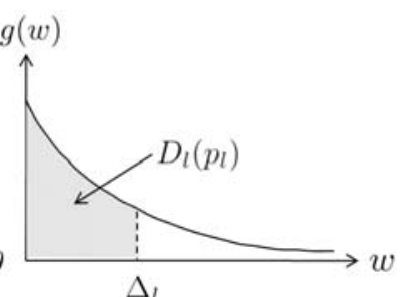

注）図では, 分布関数を下に凸な関数として表現しているが, 以降の分析において, 2 階条件は本質的な仮定ではない.

図-2 準需要関数の構造

シャリア適格でなければならないという制約のために, 収益性が制約される可能性もある。 また, 借り手側が イスラーム金融を採用することによる不確実性や知識 の習得など，取引そのものに実質的な費用がかかる場 合も考えられる．このようにイスラム金融を用いる際 に要する取引費用を $w$ と表す， $w$ は，非負の実数空間 $\boldsymbol{R}_{+}=[0,+\infty)$ 上において, 密度関数 $g(w)$, 分布関数 $G(w)$ に従う確率変数であると仮定する. ただし， $g(\cdot)$ の関数形は, $g^{\prime}(\cdot)<0$ を満たすと仮定する. インフラ 事業の場合には, 事業そのものがイスラーム教の教義 で定められた禁制品にかかわることによる制約は小さ いと考えられる．むしろ，借り手がイスラーム銀行か ら借り入れる際の取引費用は, 借り入れる際に必要な 知識（取引方法やイスラーム金融に伴うリスク）の蓄 積の有無に依存する. 借り手は, 確率変数 $w$ が確定し た後に, イスラーム銀行から借り入れるか, 通常銀行 から借り入れるかを決定する．また，借り手は，預金 者と異なり，イスラーム金融から借り入れること自体 から追加的な効用を得ることはなく, 純粋に経済的動 機にのみ基づいて借入先を決定すると仮定する，イス ラーム銀行から融資を受けた借り手の効用を $v_{S}$, 通常 銀行から融資を受けた借り手の効用を $v_{N}$ を

$$
\left\{\begin{array}{l}
v_{S}=r-w-p_{l} \\
v_{N}=r-q_{l}
\end{array}\right.
$$

と定義する.

\section{(2) 準需要関数}

イスラーム銀行の貸出返済額 $p_{d}$ と通常銀行の貸出返 済額 $q_{d}$ の差を $\Delta_{d}=q_{d}-p_{d}$ と表す. この時, イスラー 厶効用 $\theta$ の預金者の銀行選択行動は,

$$
\begin{cases}\text { イスラーム銀行に預金 } & \theta \geq \Delta_{d} \\ \text { 通常銀行に預金 } & \theta<\Delta_{d}\end{cases}
$$

と表される.ただし， $\Delta_{d}<0$ ，すなわちイスラーム銀 行の預金返済額が通常銀行よりも高い預金返済額を設 定している場合には，すべての預金者がイスラーム銀 行に預金する．このとき，イスラーム金融と伝統的金
融が共存し得ない. このため, $\Delta_{d} \geq 0$ の場合に議論を 限定する.イスラーム銀行の預金市場における準需要 関数 (quasi-demand function) ${ }^{2)} D_{d}\left(\Delta_{d}\right)$ は,

$$
D_{d}\left(p_{d}\right)=\int_{\Delta_{d}}^{+\infty} f(\theta) d \theta=F\left(\theta \geq \Delta_{d}\right)
$$

と表すことができる (図-2 参照). $f^{\prime}(\cdot)<0$ から,$D_{d}^{\prime} 0$ が成立する.さらに，イスラーム銀行の預金返済額と 通常銀行の預金返済額が等しく $p_{d}=q_{d}$ が成立すると き, イスーラム効用 $\theta \geq 0$ なる預金者は, すべてイス ラーム銀行に預金する.したがって, $D_{d}\left(q_{d}\right)=1$ が成 立する. 同様に, イスラーム銀行と通常銀行の返済額 の差を $\Delta_{l}=q_{l}-p_{l}$ と表す. このとき, 借り手の銀行 選択行動は,

$$
\begin{cases}\text { イスラーム銀行から借入 } & w \leq \Delta_{l} \text { のとき } \\ \text { 通常銀行から借入 } & w>\Delta_{l} \text { のとき }\end{cases}
$$

となる. $\Delta_{l}<0$ の場合には, すべての借入人は通常銀 行から借り入れようとする。このとき, イスラーム金 融と通常金融が共存し得ない.したがって, 以下では, $\Delta p^{l} \geq 0$ すなわち $p_{l} \leq q_{l}$ の場合のみを分析対象とする. このとき,イスラーム銀行に対する借り手側の準需要 関数 $D_{l}\left(p_{l}\right)$ は,

$$
D_{l}\left(p_{l}\right)=\int_{0}^{\Delta_{l}} g(w) d w=G\left(w \leq \Delta_{l}\right)
$$

と表すことができる (図-2 参照). $g^{\prime}(\cdot)<0$ から,$D_{l}^{\prime}<$ 0 が成立する.ささらに, イスラーム銀行の貸出返済額と 通常銀行の貸出返済額が等しく $p_{l}=q_{l}$ が成立すると き, 取引費用 $w$ が $w \geq 0$ なる借り手は, すべて通常銀 行から借り入れる. このとき, $D_{d}\left(q_{l}\right)=0$ が成立する.

\section{（3）イスラーム金融市場の 2 面性}

以上の前提条件の下で, イスラーム金融市場が 2 面 市場としての性質を満たしていることを確認しておこ う.イスラーム金融市場の預金返済額が $p_{d}$, 貸出返済 額が $p_{l}$ のとき, イスラーム金融を通じて, 実際に貸し 出された資金量を $V\left(p_{d}, p_{l}\right)$ と定義する. イスラム銀行 は，集められた預金量以上の資金を貸し出すことがで きないという資金制約に直面する。したがって, 貸出市 場の準需要が預金市場の準需要を上回れば, $V\left(p_{d}, p_{l}\right)$ は預金市場の準需要と一致し, 預金市場の準需要が貸 出市場の準需要を上回れば, $V$ は貸出市場の準需要と 一致する.すなわち，

$$
V\left(p_{d}, p_{l}\right)=\min \left\{D_{d}\left(p_{d}\right), D_{l}\left(p_{l}\right)\right\}
$$

で表される. 仮に, イスラーム金融が一面的であれば, 2.(4) で議論したように, $V$ は, $p_{l}-p_{d}$ の大きさのみ に依存しなければならない.すすおち，イスラーム金 融が一面的である場合には, 任意の $\delta$ に対して,

$$
V\left(p_{d}, p_{l}\right)=V\left(p_{d}+\delta, p_{l}+\delta\right)
$$


が成立しなければならない。しかし，預金市場と貸出 市場の準需要が一致する預金返済額と貸出返済額の任 意の組み合わせ $\left(p_{d}^{\circ}, p_{l}^{\circ}\right)$ に対して,

$$
V\left(p_{d}^{\circ}, p_{l}^{\circ}\right) \neq V\left(p_{d}^{\circ}+\delta, p_{d}^{\circ}+\delta\right)
$$

が成立する (付録参照)。式 (9) は, イスラーム金融市 場が 2 面市場であることを示唆している. すなわち, イ スラーム金融の取引量が $p_{l}-p_{d}$ ではなく, 預金市場と 貸出市場における利率設定のバランスが重要であるこ とを示している.

預金市場と貸出市場の需給が一致している点からの 両市場における微小な利子率の増加に対して, 預金市 場では預金量の増加がもたらされる一方, 貸出市場で は, 貸出量の減少につながる. したがって, 一面市場 においては預金市場での利子率の増加を貸出市場の貸 出返済額の増加で相殺することが可能となるが，この ような調整メカニズムは 2 面市場において機能しない.

\section{(4) 社会的最適解}

経済的効率性の評価のためのベンチマークとして, 社 会的に最適な預金返済額及び貸出返済額を導出する.イ スラーム銀行は, 預金者から預かった預金を, すべて 貸し出さなければならないと仮定する，イスラーム銀 行の預金者が, 自らの預金が必ずシャリア適格な事業 に投資されていることによって，イスラーム効用を獲 得する．仮に，この仮定を緩和すれば，イスラーム銀 行への預金者は, 預金が必ずしも実際の投資に回され ていない場合でもイスラーム効用を獲得することを意 味する．イスラーム銀行に預金しただけで預金者がイ スラーム効用を獲得すれば，イスラーム銀行が投資に 回す当てがないにもかかわらず，イスラーム銀行が預 金を受け入れることが望ましい場合が生じる可能性が ある.このような可能性を排除するために, イスラー ム銀行が受け入れた預金は, すべて貸し出されると仮 定している.

まず，イスラーム銀行部門が獲得する余剩 $\phi\left(p_{d}, p_{l}\right)$ は, $q_{d}=q_{l}$ 及び $D_{d}\left(p_{d}\right)=D_{l}\left(p_{l}\right)$ の仮定から,

$$
\begin{aligned}
\phi\left(p_{d}, p_{l}\right) & =p_{l} \times \min \left\{D_{d}\left(p_{d}\right), D_{l}\left(p_{l}\right)\right\} \\
& -p_{d} D_{d}\left(p_{d}\right) \\
& =\Delta_{d} D_{d}\left(p_{d}\right)-\Delta_{l} D_{l}\left(p_{l}\right)
\end{aligned}
$$

と表される. 通常銀行部門の余剩は, 完全競争市場の 仮定から, 必然的にゼロとなる. 次に, 借り手の余剩 $\psi_{l}\left(p_{l}\right)$ は, イスラーム銀行からの借り手の余剩と, 通常 銀行からの借り手の余剩の和である.すなわち,

$$
\begin{aligned}
\psi_{l}\left(p_{l}\right) & =\int_{0}^{\Delta_{l}}\left(r-w-p_{l}\right) g(w) d w \\
& +\int_{\Delta_{l}}^{+\infty}\left(r-q_{l}\right) g(w) d w
\end{aligned}
$$

$$
=\int_{0}^{\Delta_{l}}\left(\Delta_{l}-w\right) g(w) d w+r-q_{l}
$$

と導出できる. 預金者の余剩 $\psi_{d}\left(p_{d}\right)$ は，イスラーム銀 行からの預金者の余剩と, 通常銀行からの預金者の余 剩の和である. すなわち,

$$
\begin{aligned}
\psi_{d}\left(p_{d}\right) & =\int_{0}^{\Delta_{d}}\left(q_{d}-1\right) f(\theta) d \theta \\
& +\int_{\Delta_{d}}^{+\infty}\left(p_{d}-1+\theta\right) f(\theta) d \theta \\
& =\int_{\Delta_{d}}^{+\infty}\left(\theta-\Delta_{d}\right) f(\theta) d \theta+q_{d}-1
\end{aligned}
$$

と導出できる. 金融市場全体の総余剩 $W\left(p_{d}, p_{l}\right)$ は, 以 上のイスラーム銀行及び通常銀行部門の余剩と預金者 の余剩の和として定義される. したがって,

$$
\begin{aligned}
W\left(p_{d}, p_{l}\right) & =\phi\left(p_{d}, p_{l}\right)+\psi_{d}\left(p_{d}\right)+\psi_{l}\left(p_{l}\right) \\
& =\int_{\Delta_{d}}^{+\infty} \theta f(\theta) d \theta+q_{d}-1 \\
& -\int_{0}^{\Delta_{l}} w g(w) d w+r-q_{l}
\end{aligned}
$$

と表される. 社会的最適な預金返済額 $p_{d}^{F B}$ 及び $p_{l}^{F B}$ を 求める問題は,

$$
\begin{aligned}
& \left(p_{d}^{F B}, p_{l}^{F B}\right)=\arg \max _{\left(p_{d}, p_{l}\right)} W\left(p_{d}, p_{l}\right) \\
\text { s.t. } & D_{d}\left(p_{d}\right)=D_{l}\left(p_{l}\right)
\end{aligned}
$$

と定式化できる. 以上の最適化問題を解くと, 次の補 題 1 が導かれる（証明は付録参照）.

補題 1 社会的最適な利子率 $p_{d}^{F B}$ 及び $p_{l}^{F B}$ は, 以下 の性質を満足する.

$$
\begin{aligned}
& p_{d}^{F B}=p_{l}^{F B} \\
& D_{d}\left(p_{d}^{F B}\right)=D_{l}\left(p_{l}^{F B}\right)
\end{aligned}
$$

補題 1 は, 社会的厚生が最大化されるためには，1）預 金市場と貸出市場の準需要が一致すること，2）預金返 済額と貸出返済額が一致することが要請されることを 示している. 具体的な導出過程は, 付録に譲るが, イ スラーム金融の取引量を $V\left(\Delta_{d}, \Delta_{l}\right)$ から微小に増加さ せた場合の社会的厚生の集計的なイスラーム効用の限 界効用は $\Delta_{d}$ であり, 借り手側の集計的な取引費用の限 界費用は $\Delta_{l}$ と表される.すすなわち, 社会的厚生を最大 化するイスラーム金融の取引量は, 集計レベルのイス ラーム金融取引に対する限界効用とイスラーム金融の 限界費用が一致する点であると解釈することができる.

\section{（5）イスラーム銀行の独占行動モデル}

イスラーム金融の萌芽期では，イスラーム金融を扱 う銀行の数は限定的である. 萌芽期のイスラーム金融 市場における金利の決定構造を明らかにするため, イス 
ラーム銀行の利子率の決定が, イスラーム銀行の取引量 に影響を与える独占的な市場環境におけるイスラーム 銀行の行動を分析する. イスラーム銀行は, 自らの利潤 の最大化を目的として, 預金返済額 $p_{d}$ 及び貸出返済額 $p_{l}$ を決定する. 社会的厚生最大化モデルと同様に, イス ラーム銀行は，預金者から集めた預金をすべて貸し出 さなければならない需給一致条件を仮定する (図-3 参 照). なお, 需給一致条件を仮定しなくとも, イスラー ム銀行の利潤最大化行動の結果, 結果的に需給一致均 衡が得られることは容易に確認できる，このとき，イ スラーム銀行の利潤最大化問題は,

$$
\begin{array}{ll} 
& \max _{\left(p_{d}, p_{l}\right)} \phi\left(p_{d}, p_{l}\right) \\
\text { s.t. } & D_{d}\left(p_{d}\right)=D_{l}\left(p_{l}\right)
\end{array}
$$

と定式化できる. 独占市場の下でイスラーム銀行が選 択する最適解 $\left(p_{d}{ }^{M O}, p_{l}{ }^{M O}\right)$ が満たす条件を導くと, 次 の命題 1 が得られる (証明は付録参照).

命題 1 イスラーム銀行が独占的利益を最大化する預金利 回り $p_{d}{ }^{M O}$ 及び貸出返済額 $p_{l}{ }^{M O}$ は以下の式を満たす.

$$
\begin{aligned}
& p_{l}^{M O}=\alpha p_{d}^{M O} \\
& D_{l}\left(p_{l}{ }^{M O}\right)=D_{d}\left(p_{d}^{M O}\right)
\end{aligned}
$$

ただし，パラメータ $\alpha$ は以下のように定義される.

$$
\begin{aligned}
\alpha & =\frac{1-\left(1 / \eta_{d}\right)}{1-\left(1 / \eta_{l}\right)} \\
\eta_{d} & =-\frac{p_{d}\left(d D_{d} / d p_{d}\right)}{D_{d}}(<0) \\
\eta_{l} & =-\frac{p_{l}\left(d D_{l} / d p_{l}\right)}{D_{l}}(>0)
\end{aligned}
$$

イスラーム銀行が独占的に利子率を決定する場合, イ スラーム銀行は, 預金返済額に $\alpha-1$ だけ, マークアッ プした值を貸出返済額として設定する，マークアップ 率は, 預金市場の準需要の価格弾力性の絶対值が大き いほど, 小さくなり, 貸出市場の準需要の価格弾力性 が大きいほど, このとき, イスラーム銀行は, 正の利 潤を獲得する．また，ファーストベストの場合の利子 率と比較すると,

$$
p_{d}^{F B}>p_{d}^{M O} \quad p_{l}^{F B}<p_{l}^{M O}
$$

という関係が導かれる．また，前節の証明において示 したように, $p_{d}>p_{l}$ が成立する場合, 必ず社会的厚生 を改善することができる. したがって, 独占市場の下 での社会的厚生 $W\left(p_{d}^{M O}, p_{l}^{M O}\right)$ は,

$$
W\left(p_{d}^{M O}, p_{l}^{M O}\right)<W\left(p_{d}^{F B}, p_{l}^{F B}\right)
$$

が成立し, 独占市場均衡は, 社会的に非効率である.

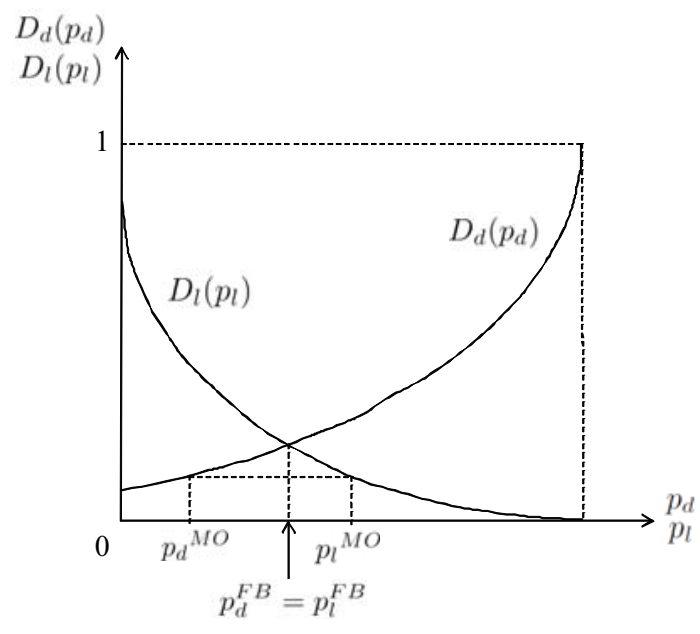

図-3 イスラーム金融市場の価格決定構造

\section{（6）ラムゼイ最適価格規制}

以上で示したように，イスラーム銀行が独占力を有 する場合には, 社会的厚生の視点から望ましい状態が 実現できない，独占市場における社会的厚生を改善す るための方策として, ラムゼイ価格による料金規制を 考える. ラムゼイ価格とは, 生産者余剩をゼロとする 制約条件の下で, 消費者余剩（すなわち, 社会的余剩) を最大化するような価格である. 3.(4)の分析結果が示 すように, 社会的最適解におけるイスラーム銀行の余 剩はゼロになる. したがって, ラムゼイ価格形成によっ て, 実現するラムゼイ最適解は, 必ず社会的最適解と 一致することが保証される。この結果を, 以下の命題 2 として示す.

命題 2 ラムゼイ最適解は, 社会的最適解と一致する.

\section{（7） 完全競争市場}

以上の分析では, ただ 1 つのイスラーム銀行が独占 的にイスラーム金融を扱う市場環境を仮定した。イス ラーム金融市場の萌芽期においては, 独占市場の前提 は妥当であると考える. 一方, 近年では, グローバル な金融蟣関のイスラーム金融市場への参入が相次いで おり，イスラーム金融市場の競争性は高まっている.

いま，あるイスラーム銀行が $\hat{p}_{l}>\hat{p}_{d}$ 及び $D_{d}\left(\hat{p}_{d}\right)=$ $D_{l}\left(\hat{p}_{d}\right)$ を満たす利子率を設定している場合を考える. このとき, イスラーム銀行は, 正の利潤を獲得する.ま た, $V\left(\hat{p}_{d}, \hat{p}_{l}\right)=\hat{V}<V\left(p_{d}^{F B}, p_{l}^{F B}\right)$ が成立している.こ こで, 新規参入の費用が無視できる場合, 新規参入の

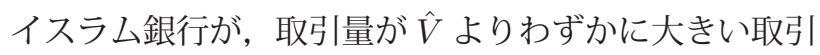
量 $\hat{V}+d V$ となるような $p_{d}, p_{l}$ を設定すれば, 厳密に正 の利潤を獲得する．このような参入過程を繰り返すこ 
とによって, 完全競争均衡では,

$$
\begin{aligned}
& p_{d}^{P C}=p_{l}^{P C} \\
& D_{d}\left(p_{d}^{P C}\right)=D_{l}\left(p_{l}^{P C}\right)
\end{aligned}
$$

を満たす利子率が実現する．補題 1 の社会的効率解の 条件式と比較することにより, 完全競争均衡は, 社会 的効率解と一致することが保証される. すなわち, 以 上の分析結果を命題 3 として示す.

命題 3 完全競争的なイスラーム金融市場における均 衡解は, 社会的最適解に一致する.

\section{4. イスラーム化の影響分析}

\section{（1）イスーラム効用の増加の影響}

イスラーム金融を 2 面市場の視点から分析したとき, イスラーム効用として表現された，人々のイスラーム に対する自覚の程度がイスラーム金融の疑似利子率に 影響を与える重要なパラメータとなる.イスラーム教 では, シャリアに従うことがすべて共同体（umma）の ためであり, その行為自体が自らの正しい生き方とし て選択されるべきものと考えている. イスラーム効用 は，人々がイスラーム金融を利用し，イスラーム社会 における正しい生き方を実践したという事実により得 られる満足度を表す．イスラーム金融がイスラーム社 会における正しい生き方のための手段であるという認 識が高まれば，イスラーム金融市場における疑似利子 率は影響を受ける。 その結果, PPP 事業においてイス ラーム金融を用いた場合の調達費用も影響を受ける．こ のような, イスラームに対する自覚が高まりの影響を 分析するために, イスラーム効用の分布関数 $F(\cdot)$ が, $F(\cdot)$ を確率的支配する分布関数 $\tilde{F}(\cdot)$ に変化したと考え る. $\tilde{F}(\cdot)$ の密度関数を $\tilde{f}(\cdot)$ と表す. 2 つ確率密度関数 の間に尤度比の単調性条件 (monotone likelihood ratio condition; MLRC) ${ }^{15)}$

$$
\frac{d(f / \tilde{f})}{d \theta}<0
$$

を仮定する. MLRC 条件 (22) は, $f / \tilde{f}$ が $\theta$ に関して 単調減少であることを要求している。このとき, 確率 分布関数 $F(\cdot)$ 及び $\tilde{F}(\cdot)$ について, 任意の $\theta$ に対して, $\tilde{F}(\theta) \leq F(\theta)$ が成立する. イスラーム効用が社会全体 として増加の方向にシフトした場合を想定している.こ のとき, 任意の $\theta$ について, 新たにシフトした分布形の 下では，それ以下の $\theta$ が実現する確率が低くなること を意味している. 関数形 $\tilde{f}$ に基づく準需要関数 $\tilde{D}^{d}$ は,

$$
\left\{\begin{array}{l}
\frac{d D_{d}\left(p_{d}\right)}{d p_{d}}>\frac{d \tilde{D}_{d}\left(p_{d}\right)}{d p_{d}}>0 \\
\tilde{D}_{d}(0)>D_{d}(0) \\
\tilde{D}_{d}\left(q_{d}\right)=D_{d}\left(q_{d}\right)=1
\end{array}\right.
$$

を満足する．分布形が $\tilde{F}$ にシフトした後の独占市場の 利子率を $p_{d}{ }^{M O \circ}, p_{l}{ }^{M O \circ}$, 社会的最適解における利子率 を $p_{d}{ }^{F B \circ}, p_{l}{ }^{F B \circ}$ と表す．このとき

$$
\begin{aligned}
& p_{d}{ }^{M O \circ}<p_{d}{ }^{M O}, p_{l}{ }^{M O \circ}<p_{l}{ }^{M O} \\
& {p_{d}}^{F B}=p_{l}{ }^{F B}>p_{d}{ }^{F B \circ}=p_{l}{ }^{F B \circ}
\end{aligned}
$$

が成立する．また，

$$
W\left(p_{d}^{F B}, p_{l}^{F B}\right)<W\left(p_{d}^{F B \circ}, p_{l}^{F B \circ}\right)
$$

が成立する. このことから, 次の命題 4 が得られる.

命題 4 預金者のイスラーム金融に対する主観的価值 が社会的に増加すれば, 社会的最適解（完全競争市場, ラムゼイ規制）及び独占市場のいずれの場合にも, 預 金返済額, 貸出返済額は減少する. その結果, PPP 事 業の資金調達費用は減少する。このとき, 社会的厚生 も必ず増加する。

\section{（2） 取引費用削減の影響}

2 面市場分析では, イスラーム金融の利用に伴う取引 費用もイスラーム金融市場における預金返済額と借入 返済額を決定する要因である。イスラーム金融の取引 費用は，シャリア適用による法的判断の不確実性や金融 取引の仕組みの標準化がまだ十分に進んでいないこと などにより生じる．取引費用は，PPP投資で資金を借 り入れる際のスポンサーといった借り手側のイスラー ム金融に対する知識が蓄積され，会計システム等の制 度的なインフラが整備されることによって, 削減され るであろう. このような, イスラーム金融システムの発 展が, PPP 事業のイスラーム金融による調達費用にど のような影響を与えるかを分析する. 3. で定式化した モデルで, 取引費用が全体的に減少する方向もシフト した場合を考えよう，取引費用が削減された結果，当 初の取引費用 $w$ の分布形 $G(\cdot)$ が $\tilde{G}(\cdot)$ に変化したとし よう. $\tilde{G}(\cdot)$ の密度関数を $\tilde{g}(\cdot)$ と表す. ただし, 前節と 同様に, 2 つ確率密度関数の間に尤度比の単調性条件

$$
\frac{d(\tilde{g} / g)}{d w}<0
$$

を仮定する.このとき, 確率分布関数 $G(\cdot)$ 及び $G(\cdot)$ に ついて, 任意の $w$ に対して, $\tilde{G}(w) \geq G(w)$ が成立す る. 分布形 $\tilde{G}$ に基づく準需要関数 $\tilde{G}_{d}$ は,

$$
\tilde{D}_{l}\left(p_{l}\right) \geq D_{l}\left(p_{l}\right)
$$

を満たす。分布形が $\tilde{G}$ にシフトした後の独占市場 の利子率を $p_{d}{ }^{M O \circ \circ}, p_{l}{ }^{M O \circ \circ}$, 社会的最適利子率を

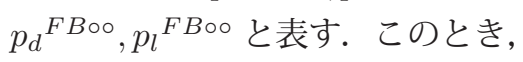

$$
\begin{aligned}
& p_{d}{ }^{M O \circ \circ}>p_{d}{ }^{M O}, p_{l}{ }^{M O \circ \circ}>p_{l}{ }^{M O} \\
& p_{d}{ }^{F B}=p_{l}{ }^{F B}<p_{d}{ }^{F B \circ \circ}=p_{l}{ }^{F B \circ \circ}
\end{aligned}
$$


が成立する.また，

$$
W\left(p_{d}{ }^{F B}, p_{l}{ }^{F B}\right)<W\left(p_{d}{ }^{F B \circ \circ}, p_{l}{ }^{F B \circ \circ}\right)
$$

が導かれる. 以上の分析結果をまとめると, 次の命題 5 が得られる.

命題 5 イスラーム金融に関する知識の蓄積と制度イ ンフラが整備され，イスラーム金融に付随する取引費 用が削減されれば，社会的最適解（完全競争市場，ラ ムゼイ規制）及び独占市場のいずれの場合にも，預金 返済額，貸出返済額は増大する，その結果，PPP 事業 の資金調達費用は増大する，このとき，社会的厚生も 必ず増加する。

\section{5. 政策的示唆}

\section{（1）イスラーム金融の発展の PPP 事業への影響}

イスラーム金融のプラットフォームとしての価值は, イスラーム教徒が「自分の預金が，シャリア適格な事業 のために活用されることによって，よりよい社会が実現 するであろう」という信念に基づく効用から生じてい る.したがって, イスラーム銀行が通常銀行が設定した 預金利子率よりも小さい疑似預金利子率を設定してい る場合でも，イスラーム効用を有するような預金者は， イスラーム銀行を選択する可能性がある。一方で，借 り手側からみれば，通常金融はイスラーム金融とは異 なり，投資対象事業がシャリア適格でなければならない という制約がない上，金融取引方法に関する標準化が 進んでおり, 取引上の法的リスクも少ない。 そのため, 採算性のみを考慮する借り手側にとって，イスラーム金 融は追加的な取引費用をもたらすために，伝統的金融 に対して貸出返済額の面で競争力を有する必要がある. 言い換えれば，イスラーム銀行は，イスラーム教徒か ら比較的安価に資金を調達することにより，シャリア 適格な事業に対してのみ，安価に貸し出すことを可能 にする仕組みである．そのため，イスラーム金融から 資金を調達する PPP 事業者は，比較的安価に事業資金 を借り入れることができることを示唆している．また， イスラーム金融市場が競争的になるほど，伝統的金融 との利子率の格差は拡大し, PPP 事業者にとって, イ スラーム金融市場からの資金調達がより魅力的になる.

イスラーム教を国教とする国々では, 積極的にイス ラーム金融のプロモーションを行っている．このよう なイスラーム金融のマーケティングにより, イスラー ム教徒のイスラーム金融の意義に対する理解が深まる 結果，イスラーム効用が増大する．イスラーム銀行が 預金者に対するマーケティングに成功すれば，疑似利 子率は減少し，安価に資金調達が可能になる。その結 果，大規模な資金調達を実施する必要がある PPP 事業
にとって, このようなマーケティングは資金調達費用 を減少させ, 結果的にインフラ整備を促進させる効果 を有する。

一方で，イスラーム金融から融資を受ける取引費用 が大きい場合，PPP 事業者による資金調達において大 きな負担となる. 特に, 非イスラーム国の企業がスポン サーとなるような事業では，イスラーム金融に関する十 分な知識を有しておらず，経験を積んでいないことも少 なくない. このような, スポンサー企業にとって, イス ラーム金融を利用することは金融取引におけるリスク 要因を増やすこととなる. しかし, 今後, 借り手側のイ スラーム金融に対する理解が深まり, リスク要因が減少 していけば，イスラーム金融を利用することによる取引 費用は減少していく可能性がある.ささらに, 近年では, バーレーン通貨庁主導の国際機関 AAOIFI (Accounting and Auditing Organization for Islamic Financial Institutions), マレーシア中央銀行主導の国際機関 IFSB (Islamic Financial Services Board) が，IMF 等の国際 機関と協力しながら，イスラーム金融に関する会計基準 や取引スキームの標準化を進めている1),16). イスラー ム金融市場の整備は，借り手側のイスラーム金融に対 する資金需要を増加させ，イスラーム金融市場の疑似 利子率は増加する. しかし, 疑似利子率の増加分は, 取 引費用の減少分から生じたものであり, 実質的な調達 費用は貸出側でも減少する。したがって，より取引費用 が小さくイスラーム金融市場にアクセスできる PPP 事 業者は，比較的安価なイスラーム金融の恩恵を享受す ることができる. 以上の結果を整理すると，イスラーム 金融の預金市場側の発展（イスラーム効用の増大）と 貸出市場側の発展（取引費用の減少）が疑似利子率に 与える影響は逆である. 2 つの効果は相殺しあうため, 疑似利子率に与える影響はどちらとも言えない。しか し，いずれの効果とも，イスラーム金融の取引量を増 大させる .

\section{（2）留保事項}

イスラーム金融の疑似利子率が，伝統的金融と比較 して必ず低いという結果は，預金者がイスラーム金融 に対して，付加的な効用を有するという前提に大きく 依存している. この前提条件は，イスラーム教徒が通常 銀行にも預金するという代替的なオプションが存在し ていることを前提としている. しかし，仮にイスラー ム教徒が通常銀行へ預金することに対して，(伝統的金 融への忌避等に起因する）禁止的な費用が伴う場合に は，必ずしも本研究で示唆した分析結果が成立する保 証はない，この場合，通常銀行にも預金せず，タンス 預金を選択している可能性は否定できない. イスラム 金融は，このようなイスラーム教徒に対して，預金す 
るという選択肢を与えたことになり，必ずしも通常銀 行に対して, 疑似預金利子率が小さい必要はない.

以上の示唆は, イスラーム金融の 2 面市場という仮 定から生じたものである. 実際に, 理論的に導かれた 示唆が，現実的に必ず成立する保証はない. 実際に，マ レーシアのイスラーム債券流通市場における価格変動 の実績值を見ると，一般債券よりも高くなっている11). イスラーム教徒の投資家からイスラーム資産の保有需 要が強い下で, 価格が上昇することを期待してスクー クと呼ばれるシャリア適格であるイスラーム債券を買 う動きも見られる。また，前節で示唆したように，イ スラーム金融に対する資金需要の増大は, 貸出疑似利 子率の上昇をもたらす可能性もある.

\section{6. おわりに}

近年のイスラーム金融の発展は, PPP 事業の資金調 達において無視できない代替案となりつつある。本研 究では, 近年のイスラーム金融の発展が PPP 投資に与 える影響について分析するために，イスラーム金融市 場の 2 面性に着目し, 預金市場と貸出市場の両サイド の金利が同時に決定されるようなイスラーム金融市場 モデルを定式化した. さらに，市場均衡の比較静学分析 を通じて，預金者が伝統的金融に預金するよりも，イ スラーム金融に預金することによって，付加的な効用 を有する場合には，イスラーム金融の疑似利子率は貸 出市場，預金市場ともに伝統的金融よりも低くなるこ とが明らかになった．また，その傾向は，市場が完全競 争的になればなるほど，強くなることを指摘した，さ らに，預金者のイスラーム金融に対する意義の理解が 進み, より預金サイドの需要が高まれば，イスラーム 金融の取引量は増加し, 社会的厚生も増加する。 また, イスラーム金融取引の標準化が進み, イスラーム金融 を活用することによる取引費用が軽減されれば，イス ラーム金融による取引量は増大し利子率は上昇傾向と なる. 今後, PPP 事業に参入しようとする企業にとっ ては，対象事業のシャリア適格性を明らかにしたり，法 的リスクを軽減するなどの取引費用を軽減することに よって，イスラーム金融の活用は競争力を高めるため の 1 方策となる. 以下，今後に残された課題を示す. 第 1 に，留保事項でも指摘した通り，イスラーム金融市場 における金利が伝統的金融市場の金利よりも小さいと いう結論は，預金者が伝統的金融という代替案を有し ている仮定に依存している. しかし，イスラーム教徒 の預金者が伝統的金融に預金することを忌避している 場合は, 本研究で示した結果は, 必ずしも成立しない. 実際に, マレーシアのイスラーム債のように, イスラー 厶金融の金利の方が高いケースも見受けられる，本研
究で示したイスラーム金融市場の構造の妥当性に関す る実証的な研究は, 今後の課題としたい. 第 2 に, 本 研究では, 金融取引の方法として, 伝統的金融とイス ラーム金融の 2 つのプラットフォームのみを考慮した モデルを提示した。しかし，実際には，イスラーム金 融市場に参入した金融機関は，シャリア適格性の度合 いの違いを含めて，さまざまな差別化戦略を採ってい る. 第 3 に, 本研究では, イスラーム銀行の費用を無 視した. しかし, イスラーム銀行は, 事業のシャリア 適格性を保証するために, 相当の費用をかけているが, 取引量が増加するにつれて平均費用は減少する. 以上 の差別化戦略及び, 規模の経済を考慮したイスラーム 金融モデルを構築することにより，イスラーム銀行の， よりミクロレベルの戦略を分析することが可能になる.

なお，本研究を遂行するにあたり, International Islamic University Malaysia の Khairuddin Abdul Rashid 教授とマレーシア国シャリア委員会委員 Azman Mohd Noor 氏との議論より多くの知見を得ている．こ こに，謝意を表します。

\section{付録 命題及び補題の証明}

\section{イスラーム金融市場の 2 面性}

預金市場と貸出市場の準需要が一致する任意の預金返 済額と貸出返済額の組み合わせを $\left(p_{d}{ }^{\circ}, p_{l}{ }^{\circ}\right)$ と表記する. すなわち, $\left(p_{d}^{\circ}, p_{l}^{\circ}\right)$ は $D_{d}\left(p_{d}^{\circ}\right)=D_{l}\left(p_{l}^{\circ}\right)$ を満たす.こ こで, 点 $\left(p_{d}^{\circ}, p_{l}^{\circ}\right)$ から, $p_{l}^{\circ}-p_{d}{ }^{\circ}$ を一定のまま, 金利を 点 $\left(p_{d}{ }^{\circ}+\delta, p_{l}{ }^{\circ}+\delta\right)$ に動かした場合を考えよう.このとき, $D_{d}^{\prime}>0$ 及び $D_{l}^{\prime}<0$ から, $D_{d}\left(p_{d}{ }^{\circ}+\delta\right)>D_{l}\left(p_{l}^{\circ}+\delta\right)$ が 成立. したがって, 利子率ベクトルが $\left(p_{d}{ }^{\circ}+\delta, p_{l}{ }^{\circ}+\delta\right)$ のとき, 取引量は $V\left(p_{d}^{\circ}+\delta, p_{l}^{\circ}+\delta\right)=D_{l}\left(p_{l}{ }^{\circ}+\delta\right)$ となる. $D_{l}\left(p_{l}^{\circ}\right) \neq D_{l}\left(p_{l}^{\circ}+\delta\right)$ から, $V\left(p_{d}^{\circ}, p_{l}^{\circ}\right) \neq$ $V\left(p_{d}^{\circ}+\delta, p_{l}^{\circ}+\delta\right)$ が成立.

\section{補題 1 の証明}

取引量 $V$ を所与としたときの預金返済額を $p_{d}(V)$, 貸 出返済額を $p_{l}(V)$ と表す. さらに, $\Delta_{d}(V)=q_{d}-p_{d}(V)$, $\Delta_{l}(V)=q_{l}-p_{l}(V)$ とおく. このとき, 以下の恒等式

$$
\begin{aligned}
& D_{d}\left(p_{d}(V)\right)=\int_{\Delta_{d}(V)}^{+\infty} f(\theta)=V d \theta \\
& D_{l}\left(p_{l}(V)\right)=\int_{0}^{\Delta_{l}(V)} g(w) d w=V
\end{aligned}
$$

が成立する.これを $V$ に関して偏微分すると,

$$
\begin{aligned}
& \frac{d D_{d}}{d p_{d}} \frac{d p_{d}}{d V}=-\frac{d \Delta_{d}}{d V} f\left(\Delta_{d}\right)=1 \\
& \frac{d D_{l}}{d p_{l}} \frac{d p_{l}}{d V}=\frac{d \Delta_{l}}{d V} g\left(\Delta_{l}\right)=1
\end{aligned}
$$

を得る. 社会的厚生を $V$ の関数として定義し直すと

$$
W\left(p_{d}(V), p_{l}(V)\right)=\int_{\Delta_{d}(V)}^{+\infty} \theta f(\theta) d \theta+q_{d}-1
$$




$$
-\int_{0}^{\Delta_{l}(V)} w g(w) d w+r-q_{l}
$$

となる. $V$ に関する 1 階最適条件は, 次式で表せる.

$$
\begin{aligned}
\frac{d W}{d V} & =-\Delta_{d} f\left(\Delta_{d}\right) \frac{d \Delta_{d}}{d V}+\Delta_{l} g\left(\Delta_{l}\right) \frac{d \Delta_{l}}{d V} \\
& =\Delta_{d}-\Delta_{l}=0
\end{aligned}
$$

\section{命題 1 の証明}

この問題の $p_{l}$ に関する 1 階の最適条件は,

$$
\left(p_{l}-p_{d}\left(p_{l}\right)\right) \frac{d D_{l}}{d p_{l}}+\left(1-\frac{d p_{d}}{d p_{l}}\right) D_{l}\left(p_{l}\right)=0
$$

と表せる. ここで, 準需要関数の価格弾力性を, 式 (18b), (18c) と表すと, $D_{l}\left(p_{l}\right)=D_{d}\left(p_{d}\right)$ が成立するため,

$$
\frac{d p_{d}}{d p_{l}}=\frac{d D_{l} / d p_{l}}{d D_{d} / d p_{d}}=\frac{p}{p^{l}} \frac{\eta^{l}}{\eta^{d}}
$$

が成立する. 1 階の最適条件を変形することにより, 命 題 1 が成立する.

命題 4 の証明 $\quad V\left(p_{d}^{F B}, p_{l}^{F B}\right)=V^{F B}$ と表す. $\tilde{D}_{d}\left(p_{d}\right)=D_{l}\left(p_{l}\right)$ を満たす $p_{d}, p_{l}$ に対して $\tilde{V}\left(p_{d}, p_{l}\right)=$ $\tilde{D}_{d}\left(p_{d}\right)=D_{l}\left(p_{l}\right)$ を定義する. $\tilde{D}_{d}\left(p_{d}\right)=V^{F B}$ を満た す $p_{d}$ を $\bar{p}_{d}$ と表す. このとき, $\Delta D_{d}\left(p_{d}\right)>D_{d}\left(p_{d}\right)$ が 成立する任意の点において, $\bar{p}_{d}<p_{d}^{F B}=p_{l}^{F B}$ が成 立. 準需要関数がシフトした後にも取引量 $V^{F B}$ を維持 すれば $\bar{p}_{d}<p_{l}^{F B}$ となる. 命題 1 の証明と同様に, 貸 出利子率を下げ，預金利子率を上げることにより，取 引量を $V^{F B}$ から増加させることによって, 社会的厚 生を改善することができる.さらに, 社会的最適利子 率は $p_{l}^{F B}$ より必ず小さくなければならないことから, $p_{d}^{F B \circ}=p_{l}^{F B \circ}<p_{d}^{F B}=p_{l}^{F B}$ が成立する.

命題 5 の証明 命題 4 の証明と同様の考え方により, 示 すことができる.

\section{参考文献}

1) 北村歳治, 吉田悦章: 現代のイスラム金融, 日経 BP 社, 2008.
2) Rochet, J-C. and Tirole, J.: Platform competition in two-sided markets, Journal of European Economic Association, Vol. 1, No. 4, pp. 990-1029, 2003.

3) Rochet, J-C. and Tirole, J.: Two-sided markets: Progress report, RAND Journal of Economics, Vol. 37, No. 3, pp. 645-667, 2006.

4) Arabi, O.: Studies in Modern Islamic Law and Jurisprudence, Kluwer Law International, 2001.

5) El-Gamal, M.A.: Interest and the paradox of contemporary Islamic law and finance, Fordham International Law Journal, Vol. 27, No. 1, pp. 108-149, 2003.

6) El-Gamal, M.A.: Islamic finance: Law, economics, and practice, Cambridge University Press, 2006.

7) Presley, J.R. and Sessions, J.G.: Islamic economics: The emergence of a new paradigm, Economic Journal, Vol. 104, pp. 584-596, 1994.

8) Kuran, T.: Islamic economics and the islamic subeconomy, The Journal of Economic Perspective, Vol. 9, No. 4, pp. 155-173, 1995.

9) Iqbal, M. and Llewellyn, D.T.: Islamic Banking and Finance, Edward Elgar Publishing, 2002.

10) Ebrahim, M. S. and Safadi, A.: Behavioral norms in the Islamic doctrine of economics: A comment, Journal of Economic Behavior and Organization, Vol. 27, pp. 151-157, 1995.

11) Chapra, M. U.: Islam and the Economic Challenge, The Islamic Foundation, 1992.

12) Siddiqi, M. N.: Issues in Islamic Banking, The Islamic Foundation, 1983.

13) Chong, B. S. and Liu, M-H.: Islamic banking: Interest-free or interest-based?, Pacific-Basin Finance Journal, Vol. 17, pp. 125-144, 2009.

14) Aggarwal, R. K. and Yousef, T.: Islamic banking and investment financing, Journal of Money, Credit and Banking, Vol. 32, No. 1, pp. 93-120, 2000.

15) Mirrlees, J. A.: Notes on welfare economics, information and uncertainty, in Balch, D., McFadden, D., and Wu, S.-Y. (eds.): Essays in Economic Behavior under Uncertainty, North-Holland, pp. 243-258, 1974.

16）加賀隆一：プロジェクトファイナンスの実務, 金融財政 事情研究会, 2007 .

\title{
DEVELOPMENT OF ISLAMIC FINANCE AND ITS IMPACT ON PPP INVESTMENTS
}

\author{
Masamitsu ONISHI, Kiyoshi KOBAYASHI and Hidetoshi NAKANO
}

\begin{abstract}
Application of PPP (Public Private Partnership) to infrastructure developments is a common phenomenon around the world. This movement of adopting PPP allows the financial source of infrastructure development procurement to be diversified. Recent development of Islamic finance made itself remarkable as one of the alternatives for financial procurement in PPP projects. This paper proposes a formal model to analyze a mechanism of determining the rate of return (RoR), or the interest in the conventional finance, in order to derive an implication of the recent development of Islamic finance to the procurement cost of project financing projects for infrastructure. The analytical result of our paper shows that Islamic bank's RoR are lower in both of the deposit market and the lending market compared to conventional banks. Furthermore, the more religiously conscious those Muslim depositors are, the higher the RoR of Islamic finance becomes, and also the less the transaction costs are, the higher the RoR of Islamic finance becomes.
\end{abstract}

